\title{
COVID-19 Preventative Measures: Lessons for Public Health Policy
}

\author{
Shadreck Balisi ${ }^{1 *}$, Montlenyane Madisa $^{2}$ \\ ${ }^{1}$ School of Social Sciences, Department of Public Administration, Botswana Open University, Gaborone, Botswana \\ ${ }^{2}$ School of Social Sciences, Department of Public Health and Nursing Science, Botswana Open University, Gaborone, Botswana \\ Email: *sbalisi@staff.bou.ac.bw, mmadisa@staff.bou.ac.bw
}

How to cite this paper: Balisi, S., \& Madisa, M. (2021). COVID-19 Preventative Measures: Lessons for Public Health Policy. Open Journal of Social Sciences, 9, 1-14. https://doi.org/10.4236/jss.2021.97001

Received: May 25, 2021

Accepted: July 5, 2021

Published: July 8, 2021

Copyright (C) 2021 by author(s) and Scientific Research Publishing Inc. This work is licensed under the Creative Commons Attribution International License (CC BY 4.0).

http://creativecommons.org/licenses/by/4.0/ (c) (i) Open Access

\begin{abstract}
The coronavirus disease 2019 (COVID-19) has led to an unprecedented global public health crisis. COVID-19 was declared a Public Health Emergency of International Concern on January 30, 2020 and a pandemic on March 11, 2020 by the World Health Organisation (WHO). Following the COVID-19 outbreak, WHO and other public health organisations developed preventive guidelines against the disease. Using desktop research, this paper looks at current COVID-19 preventive measures and highlights some lessons for mandatory public health policy measures. The paper begins by giving a brief account on the background to coronavirus disease 2019, its modes of transmission, as well as current preventive measures against the disease. The paper concludes by recommending mandatory public health policy measures that need to be adopted to prevent, control and manage current and future similar outbreaks. In particular, considering the current COVID-19 preventative measures, the paper advances some recommendations on priority areas that could be adopted, maintained and sustained at policy level to provide direction on prevention and control of transmissible diseases. The priority areas recommended include but not limited to, risk assessment, community education, social and physical distancing strategic interventions, disinfection measures as well as the provision of Personal Protective Equipment (PPE).
\end{abstract}

\section{Keywords}

COVID-19, Preventative, Measures, Lessons, Public Policy

\section{Introduction}

This paper looks at current COVID-19 preventative measures and highlights 
some lessons for public health policy measures that can be adopted for the prevention, control and management of transmissible outbreaks. Particularly, the paper considers current COVID-19 preventative measures and recommends that some of the preventive measures be adopted as mandatory public health policy practice. The lessons highlighted and the recommendations thereof are essential in shaping future public health policies across the globe for public health disaster preparedness purposes. Furthermore, the recommended mandatory public health policy measures are essential for the prevention, management and control of current and future diseases caused by viruses which have similar modes of transmission through respiratory and contact routes.

\section{Methods}

This is a qualitative inquiry which used desktop method of research. The paper selected published and unpublished data related to COVID-19 outbreak. Sources of data selected included but not limited to official reports and journal articles published since the outbreak of COVID-19. A particular emphasis was on data relating to the origins, transmission, prevention, control, management as well as on signs and symptoms of COVID-19. Furthermore, the study looked at several studies that were carried out in the year 2020 to determine the impact of COVID-19 preventative measures on reducing the transmission rate of other communicable diseases such as Influenza.

\section{Background}

The novel coronavirus formally referred to as severe acute respiratory syndrome coronavirus 2 (SARS-CoV-2) (Gorbalenya et al., 2020) is a recently discovered coronavirus that causes the illness COVID-19 (Hill, 2020). SARS-CoV-2 belongs to a group of coronaviruses such as the severe acute respiratory syndrome (SARS)-CoV and the Middle East respiratory syndrome (MERS)-CoV. SARS-CoV-2 is the third deadliest coronavirus pandemic following SARS which lasted between 2002 and 2003, and the Middle East Respiratory Syndrome (MERS) which was witnessed in 2012 (Al-Qahtani, 2020). The background to the outbreak of COVID-19 is that, in late December 2019 a cluster of patients were admitted to hospitals in Wuhan, Hubei Province, China, with an initial diagnosis of pneumonia of an unknown etiology (Hill, 2020; Riou \& Althaus, 2020; WHO, 2020a). These patients presented a constellation of signs and symptoms such as fever, dyspnea and dry cough. The radiological findings showed bilateral lung glassy opacities (Kakodkar, Kaka \& Baig, 2020). Furthermore, the patients' social history epidemiologically linked these cases to a seafood and wet animal wholesale market in Wuhan which trades live species of bats, snakes, pangolins, and badgers (Bogoch et al., 2020; Hill, 2020; Li et al., 2020; Kakodkar, Kaka \& Baig, 2020). The diagnosis was later confirmed as the 2019 novel Coronavirus (2019-nCoV) by Chinese authorities on the $7^{\text {th }}$ of January, 2020 (WHO, 2020a).

However, even though the virus was epidemiologically linked to socio-cultural 
practices, scientists are still investigating the exact origin of the virus. Most importantly, epidemiologists have discovered that human to human transmission played a significant role in the rapid spread of infection worldwide (Li et al., 2020). The Chinese authorities initially named the virus 2019 novel coronavirus (2019-nCoV). The International Committee of Taxonomy of Viruses (ICTV) then later named the virus SARS-CoV-2 (Gorbalenya et al., 2020), which the World Health Organisation adopted for international use (WHO, 2020a). Since the virus' emerged, it has spread like wildfire, affecting the Wuhan region in a short period and making its way into all the provinces in China and many other countries worldwide (WHO, 2020a). As of February 23, 2020, over 77,000 people tested positive for SARS-CoV-2 infection in China, and $60 \%$ of these cases were from Wuhan (Kong et al., 2020). Consequently, the World Health Organisation (WHO) declared this viral pneumonia an outbreak and a public health emergency of international concern on January 30, 2020. Shortly afterwards, WHO declared COVID-19 a pandemic on the $11^{\text {th }}$ of March, 2020.

\section{Modes of Transmission}

SARS-COV-2 is highly transmissible among humans. Human to human spread of the virus is possible through droplet transmission, fecal-oral route, conjunctiva and fomites (WHO 2020a; Xu et al., 2020; Ong et al., 2020). The virus spreads mainly from person to person through small droplets from the nose or mouth, which are expelled when a person with COVID-19 coughs, sneezes, or speaks (Acter et al., 2020; Hill, 2020; WHO, 2020a). These droplets can land on or get trapped by the mucous membranes on the mouths, noses or eyes of people who are nearby (Guo et al., 2020). People can be infected with COVID-19 when they breathe in these droplets from a person infected with the virus. These droplets can also land on objects and surfaces around the person such as tables, doorknobs, handrails, light switches, countertops, handles, phones, keyboards, toilets, faucets, bank cards, and sinks. People can thus become infected by touching these objects or surfaces, then touching their eyes, nose or mouth (WHO, 2020a). Other means of SARS-CoV-2 transmission include handshaking with infected person, contact with an object or a surface carrying the virus, repeated touching of the face (eyes, nose or mouth), or exposure to excreta of infected patient (Al-Qahtani, 2020). Patients with COVID-19 can spread the infection during the pre-symptomatic phase (before symptom presentation), symptomatic phase, and clinical recovery period (Kakodkar, Kaka, \& Baig, 2020; Zhou et al., 2020). The asymptomatic patients, commonly known as asymptomatic virus carriers can also spread the infection (Zhou, Yang, Wang, et al. 2020). It is worth noting that the modes of transmission of SARS-COV-2 are similar to the spread of many communicable diseases that have been in existence in the world. For instance, Haemophilus Influenza, Marburg Virus Meningitis (meningococcal), Plague (pneumonic), SARS-COV-1 (Severe Acute Respiratory Syndrome) and 
the Middle East Respiratory Syndrome (MERS). See Table 2 for similar outbreaks with similar modes of transmission to SARS-COV-2. Hence the recommended mandatory public health policy measures in this paper will help in the prevention, management and control of these diseases as well as future similar outbreaks.

\section{COVID-19 Preventative Measures and Lessons for Public Health Policy}

The World Health Organisation (WHO) and the Centers for Disease Control and Prevention (CDC) have released public health and social measures for individuals, institutions, communities, local and national governments and international bodies to slow, prevent or stop the spread of COVID-19. The public health preventative measures are summarised in Table 1. After the WHO declared COVID-19 a pandemic, many countries across the globe declared state of public emergency and/or state of public health emergency in their territories to control and manage the spread of the disease. Preventive measures as outlined in table one including lockdowns, closing borders, schools, businesses, churches, as well as limiting the movement of people, were adopted and incorporated into the state of public health emergency guidelines of controlling, prevention and management of the spread of COVID-19. Lessons learnt from these preventive measures are that they had positive spillover effects on the prevention of existing communicable diseases such as Influenza and others. For instance, a study in Singapore "compared indicators of influenza activity in the year 2020 before and after public health measures were taken to reduce coronavirus disease (COVID-19) with the corresponding indicators from 3 preceding years. The study found out that Influenza activity declined substantially (Percentage influenza positivity decreased by $64 \%(\mathrm{p}=0.001)$ and estimated daily number of influenza cases decreased by $76 \%(p=0.002)$ in epidemiologic weeks 5 - 9 of the year 2020 compared to the preceding years), suggesting that the measures taken for COVID-19 were effective in reducing spread of other viral respiratory diseases" (Soo et al., 2020: pp. 1933-1934). Similarly a study carried out in the north and south China found that "the measures taken by the Chinese government to control SARS-CoV-2 also controlled the transmission of influenza virus, since these two viruses share the same routes and means of transmission". The study concluded that "influenza cases decreased dramatically following the application of coronavirus disease 2019 (COVID-19) control measures, and that other respiratory infectious diseases may also be prevented to some extent while fighting the pandemic of COVID-19" (Wu, 2020: p. 345).

Furthermore, another study titled "Effects of COVID-19 Prevention Measures on Other Common Infections, Taiwan" sought to determine whether preventive measures to limit transmission of SARS-CoV-2 hinder the spread of other infectious diseases such as influenza, pneumonia, enterovirus infection, and scarlet fever. The findings of the study reveal that in Taiwan, infection rates for the 
Table 1. Public health and social measures to prevent the spread of COVID-19.

\begin{tabular}{l} 
Measure \\
\hline Regularly and thoroughly wash your \\
hands with soap and water for at least \\
20 seconds or clean your hands with \\
an alcohol-based hand-rub especially \\
after you have been in a public place, \\
or after blowing your nose, \\
coughing, or sneezing. \\
\\
Maintain at least 1 - 2 metre \\
distance between yourself and others \\
(Avoid close contact with others).
\end{tabular}

Stay out of crowded places and avoid mass gatherings.

Avoid touching your eyes, nose and mouth.

Always cover your mouth and nose with a tissue or bent elbow when you cough or sneeze. Throw used tissues in the trash and wash your hands with soap and water or hand-sanitizer that contains at least $60 \%$ alcohol immediately.

Stay home and self-isolate even with minor symptoms such as cough, headache, mild fever, until you recover. Have someone bring you supplies. If you need to leave your house, wear a mask to avoid infecting others.

If you have a fever, cough and difficulty breathing, seek medical attention, but call by telephone in advance if possible and follow the directions of your local health authority.

Clean and disinfect frequently touched surfaces daily. This includes tables, doorknobs, light switches, countertops, handles, desks, phones, keyboards, toilets, faucets, and sinks.
Washing your hands with soap and water or using alcohol-based hand-rub kills viruses that may be on your hands.

CDC, 2020;

WHO, 2020b

When someone coughs, sneezes, or speaks they spray small liquid droplets from their nose or mouth which may contain virus. If you are too close, you can breathe in the droplets, including the COVID-19 virus if the person has the disease.

Where people come together in crowds, you are more likely to come into close contact with someone that has COVID-19 and it is more difficult to maintain physical distance of $1-2$ meters

Hands touch many surfaces and can pick up viruses. Once contaminated, hands can transfer the virus to your eyes, nose or mouth. From there, the virus can enter your body and infect you.

Droplets spread the virus.

By following good respiratory hygiene, you protect the people around you from viruses such as cold, flu and COVID-19.

CDC, 2020; WHO, 2020b

Avoiding contact with others will protect them from possible COVID-19 and other viruses.

National and local authorities will have the most up to date information on the situation in your area. Calling in advance will allow your health care provider to quickly direct you to the right health facility. This will also protect you and help prevent spread of viruses and other infections.

Droplets of an infected person excreted from coughs, sneezes or through talking can land into these frequently touched surfaces. People can become infected by touching these objects or surfaces, then touching their eyes, nose or mouth. 


\section{Continued}

Cover your mouth and nose with face mask or a cloth face-cover

The cloth face-cover is meant to protect when around others.

other people in case you are infected.

CDC, 2020

Source: WHO (2020b); CDC (2020b).

above named diseases were lower in 2020 than in previous seasons. This was a result of the implementation of COVID-19 preventive measures (Lee \& Lin, 2020). Accordingly, a mandatory public health policy that includes most of these guidelines will be imperative in the prevention, control and management of existing and future outbreaks.

Since the first case of COVID 19 was diagnosed in Wuhan, China, in December 2019, the virus has since spread like wildfire affecting almost all the countries around the world. At the time of writing, the virus had infected 175,665,006 people worldwide, while the number of deaths caused by Covid 19 virus disease had reached 3,790,024 (WorldoMeter, June 11, 2021). The disease is not only a public health crisis but it is now a global humanitarian disaster that caught the world off guard. Its impact has left all public health systems including that of the most resourced countries paralysed. Its devastating impact is on population health, the social, economic, and political landscape. Since the outbreak of this disease, there is a rapid rise in the number of infections and deaths. Thousands of lives have been lost including health workers who are the front-line workers of the COVID-19 outbreak. On the other hand, people are losing jobs and income. Many public and private institutions as well as formal and informal businesses have been closed while many businesses run on a crippled financial status. Towns and cities are getting deserted and the face to face social interactions, one of the basic element of being human, is abandoned, all because of the virus that is transmissible through respiratory droplets and contact routes (WHO, 2020a; Xu et al., 2020) and forcing everybody to self-isolate.

To minimise the devastating nature of outbreaks like COVID 19, it is high time countries draw from the experience of COVID 19 as well as the previous outbreaks to explore measures that can be put in place to prevent, control and manage any future outbreaks that can be transmitted by contact and respiratory droplets. People have died from similar outbreaks such as SARS, MERS and influenza. It is therefore unfortunate that COVID 19, is today claiming millions of lives when governments could have acted and/or put measures in place sooner or expeditiously to prevent the spread of such infectious diseases. Table 2 gives an example of outbreaks that could have triggered a sustainable global response towards the prevention, control and management of similar outbreaks. The World Health Organisation (WHO) together with other international organisation such as the Centre for Disease Controls (CDC) globally have developed a series of public health measures in response to each outbreak, nonetheless it appears none of these preventive measures were comprehensive enough to address the work environment, 
Table 2. Outbreaks that could have triggered a sustainable global response.

\begin{tabular}{|c|c|c|c|}
\hline Disease & Transmission & $\begin{array}{l}\text { Case Fatality } \\
\text { or mortality }\end{array}$ & Preventive measures \\
\hline $\begin{array}{l}\text { Tuberculosis } \\
\text { (pulmonary) }\end{array}$ & Airborne & $\begin{array}{l}\text { One of top } 10 \\
\text { cause of deaths }\end{array}$ & $\begin{array}{l}\text { Isolation, Respiratory hygiene/coughing } \\
\text { etiquette, hand washing, good } \\
\text { ventilation, cleaning and disinfection of } \\
\text { inanimate surfaces, protective clothing }\end{array}$ \\
\hline Ebola & $\begin{array}{l}\text { Airborne } \\
\text { and Contact }\end{array}$ & $\begin{array}{l}\text { CFR-25\% to } 90 \% \\
\text { in past outbreaks. }\end{array}$ & $\begin{array}{l}\text { Isolation, Respiratory hygiene/coughing } \\
\text { etiquette, hand washing, good } \\
\text { ventilation, cleaning and disinfection of } \\
\text { inanimate surfaces, protective clothing }\end{array}$ \\
\hline $\begin{array}{l}\text { Haemophilus } \\
\text { influenza }\end{array}$ & Droplet & MR-5\% & $\begin{array}{l}\text { Respiratory hygiene/coughing etiquette, } \\
\text { hand washing, good ventilation, cleaning } \\
\text { and disinfection of inanimate surfaces }\end{array}$ \\
\hline Marburg Virus & $\begin{array}{c}\text { Airborne } \\
\text { and Contact }\end{array}$ & CFR- $24 \%$ to $88 \%$ & $\begin{array}{l}\text { Avoid close physical contact, hand } \\
\text { washing, gloves and isolation, cleaning } \\
\text { and disinfection of inanimate surfaces }\end{array}$ \\
\hline $\begin{array}{c}\text { Meningitis } \\
\text { (meningococcal) }\end{array}$ & $\begin{array}{c}\text { Droplet } \\
\text { and Contact }\end{array}$ & $\begin{array}{l}\mathrm{CFR}=50 \% \\
\text { if untreated }\end{array}$ & $\begin{array}{l}\text { Avoid close physical contact; } \\
\text { Respiratory hygiene/coughing etiquette, } \\
\text { hand washing, good ventilation, } \\
\text { cleaning and disinfection of inanimate } \\
\text { surfaces; Vaccination }\end{array}$ \\
\hline $\begin{array}{c}\text { Plague } \\
\text { (pneumonic) }\end{array}$ & Droplet & $\begin{array}{l}\text { MR-Mortality rate } \\
\text { close to } 100 \%\end{array}$ & $\begin{array}{l}\text { Isolation, surgical mask, avoid close } \\
\text { contact of less than } 2 \text { meters } \\
\text { (deadly disease) }\end{array}$ \\
\hline $\begin{array}{c}\text { SARS } \\
\text { (Severe Acute } \\
\text { Respiratory } \\
\text { Syndrome) }\end{array}$ & $\begin{array}{c}\text { Airborne } \\
\text { and Contact }\end{array}$ & CFR: $0 \%-50 \%$ & $\begin{array}{l}\text { Avoid close physical contact; Respiratory } \\
\text { hygiene/coughing etiquette, hand } \\
\text { washing, good ventilation, cleaning } \\
\text { and disinfection of inanimate surfaces; }\end{array}$ \\
\hline $\begin{array}{l}\text { Middle East } \\
\text { Respiratory } \\
\text { Syndrome } \\
\text { (MERS) }\end{array}$ & $\begin{array}{c}\text { Airborne } \\
\text { and Contact }\end{array}$ & CFR: $30 \%$ & Avoid close physical contact; \\
\hline COVID-19 & $\begin{array}{l}\text { Airborne } \\
\text { and Contact }\end{array}$ & CFR: $1.3 \%$ & $\begin{array}{l}\text { Avoid close physical contact; } \\
\text { Respiratory hygiene/coughing etiquette, } \\
\text { hand washing, good ventilation, } \\
\text { cleaning and disinfection of inanimate } \\
\text { surfaces; Vaccination }\end{array}$ \\
\hline
\end{tabular}

Source: CDC (2019); Lefebvre et al. (2014); Sharma et al. (2020); WHO (2017, 2018, 2021); Zhu et al. (2020).

the workforce, public places, future similar outbreaks and be sustainable over the years. Therefore, drawing from the current public health measures and guidelines advanced by the WHO and the CDC on the prevention of COVID-19, this article seeks to make recommendations for future mandatory public health policy measures post COVID-19. The recommendations are expected to shape the future public health policy direction specifically on the prevention, management and control of the spread of infectious diseases. 


\section{Recommended Public Health Policy Measures Post-COVID-19}

Drawing from COVID 19 and other outbreaks, developing strategies to achieve preparedness for emerging communicable diseases could help minimize the impact of future outbreaks on communities, businesses, institutions and the economy. Identifying basic preventive measures and instituting them as a norm for individuals, communities, institutions and organizations could help prevent and control the spread of current and future outbreaks with similar mode of transmissions.

Therefore, the rationale behind the recommended mandatory post COVID-19 public health policy measures is to provide a framework for national preparedness and global involvement in the prevention, management and control of future outbreaks. Considering the current COVID-19 preventative measures, this paper therefore, advances some recommendations on priority areas that could be adopted, maintained and sustained at policy level to provide direction on prevention and control of transmissible diseases. The priority areas recommended include but not limited to, risk assessment, community education, social and physical distancing strategic interventions, air and surface disinfection measures as well as the provision of Personal Protective Equipment (PPE). The recommended priority areas are discussed below:

\section{Risk Assessment}

Risk assessment ensures that countries are prepared for emerging infectious diseases by providing information about what is likely to go wrong, who would be affected and the likely consequences that may occur as a result of the outbreak. It also helps in resource allocation and identification of mitigation strategies (Brookes et al., 2015). Therefore, the establishment of risk assessment strategies and enforcing its implementation is crucial for disease outbreaks preparedness and subsequent prevention, management and control of current and future outbreaks.

\section{Community Education and Public Risk Communication}

Lessons learnt from COVID-19 preventative measures is that making community education and communicating risks to community well on time should be made strategic priority in the control and prevention of infectious diseases. Community education should be made a priority development agenda as well as a core responsibility of all sectors (public, private, NGO's and civil society communities). Making community education a strategic priority, will help in enforcing delivery of health education and promotion messages to individual or groups and thereby empowering them adopt healthy lifestyles.

\section{Social and Physical Distancing Strategic Interventions}

Social and physical distancing came long before the emergence of COVID-19 
and it has beard positive results in the control of transmissible diseases like tuberculosis, measles, chicken pox and many others. Therefore, instituting policies and guidelines that enforce social distancing in public places such as public transport terminals, business entities, workplaces, schools and social gatherings would be ideal for preventing current and future transmissions. The following are strategic interventions that can be adopted as public health policy measures to enforce social and physical distancing:

\section{1) Re-engineering workplace structures and office sharing}

Today's workplaces are characterized by shared areas. Post COVID-19, sharing an office is discouraged, however, whenever this is not possible, a shared office should be spacious enough to allow for social distancing measures. For instance, officers sharing an office should be placed at least two (2) meters apart from each other. Small and poorly ventilated offices pose a challenge given the recent outbreaks of airborne, droplets or contact transmissions. Shared offices should be well ventilated and equipped with equipment that can be easily disinfected. Failing which, teleworking should be emphasized in all organizations or institutions.

2) Supplementing physical contact services with online or contactless services

Post COVID-19, health policy should shift towards a mandatory requirement that in addition to the current normal way of doing business, restaurants, retail shops, building materials hardwares, clothing stores and many other businesses should have online shopping and home delivery services. This is a social distancing measure that will significantly reduce the number of people crowding at the same place seeking for services. To avoid crowding at the workplace by customers, there is need to invest in online business platforms that will require clients to access services at the comfort of their homes. For example, commercial banks should have effective online banking platforms that will discourage people from visiting banking halls for financial transactions. Similarly, government services such as company registration, acquiring permits, trade licences, renewal of a driver's license, filing tax returns and many other services should be done online.

\section{3) Working from Home (WFH)}

One of the social distancing measures during the Coronavirus (COVID-19) pandemic is the encouragement to work from home (WFH) in order to decongest the workplace. This paper recommends that WFH initiative be a new normal post COVID-19, more especially for work which does not require employees to be at the workplace. However, there are some work Activities which require that employees be physically present at the workplace. For instance, employees in the construction and manufacturing industries need to be physically present at the workplace. WFH can be done alternatively through shift work. Shift work can be done on weekly basis, every after two days or through morning and afternoon shifts. Employees can alternate from WFH and working from the office (WFO) through scheduled shift work. Shift work arrangement or alternate work policies 
can be adopted to meet the demand of an institution or organization. Labour laws can be used to guide companies that may need staff to work on 24 hour shifts to avoid unnecessary conflicts or exploitation of employees. Organizations and companies may also develop their own WFH policies and/or agreements that should be binding to their employees.

Working from home or teleworking has helped mitigate the public health and economic consequences of the COVID-19 pandemic (Begr, Bonnet, \& Soares, 2020). Therefore, WFH initiative will also assist in the prevention, control and management of current transmissible diseases and future outbreaks. Working from home is not a new concept, but uptake especially in the low and middle income countries has remained relatively low. According to Berg, Bonnet and Soares (2020), prior to COVID-19, working from home has remained as low as $2.9 \%$ globally. It is only during COVID-19 outbreak that the world started appreciating working from home as innovative approach that could address public health issues as well as socio economic issues. Working from home did not only prevent transmission of COVID-19, it also has economic benefits of not traveling every day to work, as well as the social benefits of spending quality time with families. Since the outbreak of COVID-19, working from home has risen to $93 \%$ in some organizations, especially in high income countries. All this is to technologies in place to facilitate regular communication of employees from their home environment. Therefore, to be disaster-prepared and proactive in the prevention and control of spread of infections, enforcing social distancing by means of working from home, and leveraging on the available technology can help countries, especially the developing countries, to be successful in the adoption of the innovation of teleworking.

\section{Air and Surface Disinfection Measures}

While disinfection measures cannot eliminate the spread of some infectious diseases completely, they can significantly minimize the risk of infection. Hence disinfection should be enforced at policy level. Hygiene coupled with social distancing and behavior change has the potential to control most if not all the life threatening infectious diseases. Therefore, a strategic intervention which enforces enhancement of cleaning and disinfection practices is recommended. Public health policy should advocate for training of employees on proper cleaning and disinfection of surfaces and the environment. A lot of attention should be paid to public places and work environment. Public places such as schools, shopping malls, markets, business areas and public transport terminals (airports, train stations, taxi and bus ranks) are always crowded with large public gatherings. Therefore, public places are often considered hotspots for the spread of diseases. Similarly, the workplace (offices), for instance, manufacturing companies, mines, construction industry, government and some private business offices are considered hotspots for the spread of diseases simply because that is the area where consumers and contractors interact with the service providers and vice versa. The disinfection measures that could be implemented in public places to control 
the spread of infections are discussed below:

\section{1) Regular cleaning and Disinfecting}

Post COVID-19, there should be a mandatory policy that compels all shopping malls, the workplace, public transportation terminals, schools and other public places to promote regular and thorough hand-washing by employees, contractors, travellers and customers. This can be done by displaying posters promoting handwashing, additionally ensuring/verifying that travellers, staff, customers, and contractors have access to sites/points designated for washing hands with soap and water, and also placing sanitizing hand-rub self-dispensers in prominent places such as corridors, boardrooms, waiting rooms, toilets, as well as on entrance and exit points around the workplace, shopping malls, public places such as recreational parks, restaurants, retail shops, clothing shops, building materials shops and airports. The promotion of hand-washing can be done by advocating for hand-washing through a) establishing public policies and funding decisions that enforce hand-washing cleaning practices. b) Educating communities about appropriate hand-washing techniques c) Reinforcing behaviour change through ongoing education in public places, providing resources necessary for proper and sustainable hand-washing in public places, including business areas like shops or airports.

Furthermore, frequently touched surfaces such as shopping trolleys/carts and airport baggage trolleys should be frequently cleaned and disinfected after each user. The paper recommends, for instance, trolleys should be stored in areas/rows visibly labelled "Disinfected, Ready for Use" and "Not Ready for Use". Customers will be easily informed about which trolleys are ready to be used and which trolleys are not ready for use. Thus, a mandatory public health policy is desirable to enforce these measures in the retail market and other businesses. Cleaning and disinfection is a fundamental component of any infection prevention and control program. Drawing from lessons learned from the current pandemic and previous outbreaks, it is evident that disinfection and thorough cleaning of public places is a fundamental component of any infection prevention and control program. The public can play a critical role in the prevention and control of infectious diseases by adopting frequent cleaning and disinfection of public places as a lifestyle. Therefore, in order to be effective in prevention and control of infections, government should ensure that there is an environmental leaning and disinfection policy that guide all institutions, organizations, companies or businesses in the prevention of diseases. Countries need policies and guidelines that outline activities that constitute appropriate cleaning and disinfection in public places; appropriate equipment and chemicals to be used in cleaning and disinfection, monitoring strategies such as audit cleaning and disinfection services, as well as acts that enforce environmental cleaning and disinfection of public places.

\section{2) Hands Free Cleaning and Disinfection Gadgets and Doors}

It is also highly recommended that in order to prevent the spread of diseases, public health policy should shift towards a mandatory requirement that all pub- 
lic toilets in airports, shopping malls and at the workplace must have hands-free cleaning and disinfection gadgets such as automatic sensor water taps/faucets and sensor hand soap/sanitizer dispensers. This will help minimise many people touching the same surfaces and thereby successfully reducing contamination of public surfaces and the transmission of diseases thereof. Additionally, common entrance and exit points should be replaced with automatic doors to avoid many people opening the same door by touching it.

\section{Provision of Personal Protective Equipment (PPE)}

Personal protective equipment should also be considered as a preventive measure. The use of gloves, protective garments, masks should be considered for some activities that may put individuals at risk of transmitting or acquiring infections. A policy enforcing the use of PPE is essential because it would also compel institutions to carry out risk assessment regularly and budget for PPE.

\section{Conclusion}

Post-COVID-19, current preventive measures as outlined in Table 1 and in other sections of this paper should be maintained and instituted as mandatory public health policy measures except for measures that are appropriate only when there is an outbreak. For instance, the requirement to wear a face mask or face cloth in public is appropriate when there is an outbreak. In addition, this article has recommended some public health measures that can be adopted as future public health policies across the globe. These recommended post-COVID-19 public health policy measures are essential for mitigating the spread and impact of disease outbreaks in the future. Therefore, these recommendations serve as public health disaster preparedness measures. Furthermore, these measures are also equally important to prevent the spread of existing diseases that are contagious as detailed in Table 2. Future studies and/or articles should focus on industry specific post-COVID-19 public health policy measures and or guidelines. For instance, there is need for specific public health recommendations in the transport sector, education sector, construction sector and the health sector. Future studies should also focus more on the impact of COVID-19 preventive measures on existing transmissible diseases with a special emphasis on how the implementation of these measures potentially reduces the transmission of specific diseases. Currently, few studies some of which have been cited in this paper, focused on the impact of COVID-19 preventive measures on reducing the transmission of the Influenza virus.

\section{Conflicts of Interest}

The authors declare no conflicts of interest regarding the publication of this paper.

\section{References}

Acter, T., Uddin, N., Das, J., Akhter, A., Choudhury, T. R., \& Kim, S. (2020). Evolution of 
Severe Acute Respiratory Syndrome Coronavirus 2 (SARS-CoV-2) as Coronavirus Disease 2019 (COVID-19) Pandemic: A Global Health Emergency. Science of the Total Environment, 730, Article ID: 138996. https://doi.org/10.1016/j.scitotenv.2020.138996

Al-Qahtani, A. A. (2020). Severe Acute Respiratory Syndrome Coronavirus 2 (SARS-CoV-2): Emergence, History, Basic and Clinical Aspects. Saudi Journal of Biological Sciences, 27, 2531-2538. https://doi.org/10.1016/j.sjbs.2020.04.033

Berg, J., Bonnet, F., \& Soares, S. (2020). Working from Home: Estimating the Worldwide Potential. VoxEU CEPR Policy Portal, 11.

Bogoch, I. I., Watts, A., Thomas-Bachli, A., Huber, C., Kraemer, M. U., \& Khan, K. (2020). Pneumonia of Unknown Aetiology in Wuhan, China: Potential for International Spread via Commercial Air Travel. Journal of Travel Medicine, 27, taaa008. https://doi.org/10.1093/jtm/taaa008

Brookes, V. J., Hernandez-Jover, M., Black, P. F., \& Ward, M. P. (2015). Preparedness for Emerging Infectious Diseases: Pathways from Anticipation to Action. Epidemiology \& Infection, 143, 2043-2058. https://doi.org/10.1017/S095026881400315X

CDC (2019). Type and Duration of Precautions Recommended for Selected Infections and Conditions.

https://www.cdc.gov/infectioncontrol/guidelines/isolation/appendix/type-duration-pre cautions.html

CDC (2020). Coronavirus Disease 2019 (COVID-19): How to Protect Yourself \& Others. Atlanta, GA: Centers for Disease Control and Prevention (CDC). https://www.cdc.gov/coronavirus/2019-ncov/prevent-getting-sick/prevention.html

Gorbalenya, A. E., Baker, S. C., Baric, R., Groot, R. J. D., Drosten, C., Gulyaeva, A. A., Ziebuhr, J. et al. (2020). Severe Acute Respiratory Syndrome-Related Coronavirus: The Species and Its Viruses-A Statement of the Coronavirus Study Group. https://doi.org/10.1101/2020.02.07.937862

Guo, Y. R., Cao, Q. D., Hong, Z. S., Tan, Y. Y., Chen, S. D., Jin, H. J., Yan, Y. et al. (2020). The Origin, Transmission and Clinical Therapies on Coronavirus Disease 2019 (COVID-19) Outbreak-An Update on the Status. Military Medical Research, 7, 1-10. https://doi.org/10.1186/s40779-020-00240-0

Hill, B. (2020). Coronavirus: Origins, Signs, Prevention and Management of Patients. British Journal of Nursing, 29, 399-402. https://doi.org/10.12968/bjon.2020.29.7.399

Kakodkar, P., Kaka, N., \& Baig, M. N. (2020). A Comprehensive Literature Review on the Clinical Presentation, and Management of the Pandemic Coronavirus Disease 2019 (COVID-19). Cureus, 12, e7560. https://doi.org/10.7759/cureus.7560

Kong, W. H., Li, Y., Peng, M. W., Kong, D. G., Yang, X. B., Wang, L., \& Liu, M. Q. (2020). SARS-CoV-2 Detection in Patients with Influenza-Like Illness. Nature Microbiology, 5, 675-678. https://doi.org/10.1038/s41564-020-0713-1

Lee, H. H., \& Lin, S. H. (2020). Effects of COVID-19 Prevention Measures on Other Common Infections, Taiwan. Emerging Infectious Diseases, 26, 2509-2511. https://doi.org/10.3201/eid2610.203193

Lefebvre, A., Fiet, C., Belpois-Duchamp, C., Tiv, M., Astruc, K., \& Glélé, L. A. (2014). Case Fatality Rates of Ebola Virus Diseases: A Meta-Analysis of World Health Organization Data. Médecine et maladies infectieuses, 44, 412-416. https://doi.org/10.1016/j.medmal.2014.08.005

Li, R., Pei, S., Chen, B., Song, Y., Zhang, T., Yang, W., \& Shaman, J. (2020). Substantial Undocumented Infection Facilitates the Rapid Dissemination of Novel Coronavirus (SARS-CoV-2). Science, 368, 489-493. https://doi.org/10.1126/science.abb3221 
Ong, S. W. X., Tan, Y. K., Chia, P. Y., Lee, T. H., Ng, O. T., Wong, M. S. Y., \& Marimuthu, K. (2020). Air, Surface Environmental, and Personal Protective Equipment Contamination by Severe Acute Respiratory Syndrome Coronavirus 2 (SARS-CoV-2) from a Symptomatic Patient. JAMA, 323, 1610-1612. https://doi.org/10.1001/jama.2020.3227

Riou, J., \& Althaus, C. L. (2020). Pattern of Early Human-to-Human Transmission of Wuhan 2019 Novel Coronavirus (2019-nCoV), December 2019 to January 2020. Eurosurveillance, 25, pii=2000058. https://doi.org/10.2807/1560-7917.ES.2020.25.4.2000058

Sharma, R., Agarwal, M., Gupta, M., Somendra, S., \& Saxena, S. K. (2020). Clinical Characteristics and Differential Clinical Diagnosis of Novel Coronavirus Disease 2019 (COVID-19). In Coronavirus Disease 2019 (COVID-19) (pp. 55-70). Singapore: Springer. https://doi.org/10.1007/978-981-15-4814-7 6

Soo, R. J. J., Chiew, C. J., Ma, S., Pung, R., \& Lee, V. (2020). Decreased Influenza Incidence under COVID-19 Control Measures, Singapore. Emerging Infectious Diseases, 26, 1933. https://doi.org/10.3201/eid2608.201229

WHO (2017). Plague. https://www.who.int/news-room/fact-sheets/detail/plague

WHO (2018). Meningococcal Meningitis.

https://www.who.int/news-room/fact-sheets/detail/meningococcal-meningitis

WHO (2020a). Report of the Who-China Joint Mission on Coronavirus Disease 2019 (COVID-19).

WHO (2020b). Coronavirus Disease (COVID-19) Advice for the Public. https://www.who.int/emergencies/diseases/novel-coronavirus-2019/advice-for-public

WHO (2021). Ebola Virus Disease. https://www.who.int/news-room/fact-sheets/ebola-virus-disease

WorldoMeter, Covid 19 Coronavirus Pandemic. https://www.worldometers.info/coronavirus/?utm campaign=homeAdvegas1

Wu, D., Lu, J., Liu, Y., Zhang, Z., \& Luo, L. (2020). Positive Effects of COVID-19 Control Measures on Influenza Prevention. International Journal of Infectious Diseases, 95, 345-346. https://doi.org/10.1016/j.ijid.2020.04.009

Xu, L., Zhang, X., Song, W., Sun, B., Mu, J., Wang, B., Dong, X. et al. (2020). Conjunctival Polymerase Chain Reaction-Tests of 2019 Novel Coronavirus in Patients in Shenyang, China. Research Square. https://doi.org/10.21203/rs.3.rs-17648/v1

Zhou, P., Yang, X. L., Wang, X. G., Hu, B., Zhang, L., Zhang, W., Shi, Z. L. et al. (2020). A Pneumonia Outbreak Associated with a New Coronavirus of Probable Bat Origin. Nature, 579, 270-273.

Zhu, Z., Lian, X., Su, X., Wu, W., Marraro, G. A., \& Zeng, Y. (2020). From SARS and MERS to COVID-19: A Brief Summary and Comparison of Severe Acute Respiratory Infections Caused by Three Highly Pathogenic Human Coronaviruses. Respiratory Research, 21, 1-14. https://doi.org/10.1186/s12931-020-01479-w 